ROCZNIKI PEDAGOGICZNE

Tom 12(48), numer $3-2020$

DOI: https://doi.org/10.18290/rped20123-6

KS. ADAM MAJ

\title{
ZJAWISKO LĘKU W PERSONALISTYCZNEJ PERSPEKTYWIE
}

Lęk jest zjawiskiem uniwersalnym, wciąż poznawanym i nieco tajemniczym. Stanowi przedmiot różnorodnych nauk i ujęć interdyscyplinarnych.

Z punktu widzenia pedagogiki, a taki przyjmujemy, zjawisko lęku można rozpatrywać jako komponent egzystencjalny warunkujący powodzenie czy niepowodzenie wychowawcze, jako korelat działania wychowawczego czy sytuacji wychowawczej. Zjawisko lęku wychowanka jest realistycznym wyzwaniem, na które pedagog powinien odpowiedzieć działaniem adekwatnym do postawionej diagnozy, przejawiającym się w aktywności ogólnowychowawczej, profilaktycznej i terapeutycznej. Do takich działań diagnostycznych i pomocy psychopedagogicznej zobowiązana jest polska szkoła (Rozporządzenie, 2017).

Mimo że lęk jest zjawiskiem naturalnym, to jednak w niektórych przypadkach pojawia się w stadium patologicznym jako zaburzenie lękowe, wymagające interwencji specjalistycznej (psychologicznej, medycznej, farmakologicznej). W każdych okolicznościach pozostaje doświadczeniem osobowym, ogarniającym człowieka całościowo, rzutującym na jego wielowymiarowe funkcjonowanie, które implikuje holistyczne $\mathrm{i}$ integralne podejście do jego trudnych doświadczeń, cierpienia, choroby i zaburzeń (Ramsey, 1977; Frank1, 1984; Hołub, 2010). Odpowiednią podstawę teoretyczną dla osobowego modelu terapii i wychowania stanowi personalizm jako kierunek kulturowy (m.in. filozoficzny, teologiczny, pedagogiczny).

W tym kontekście przedmiotem analizy, stanowiącej zaledwie zarys problematyki, jest zjawisko lęku w perspektywie personalistycznej, jej podstawowych kategorii, eksponowanych w pedagogice personalistycznej. Przedmiot

Ks. dr hab. ADAm MAJ, prof. KUL - Katedra Dydaktyki, Edukacji Szkolnej i Pedeutologii, Instytut Pedagogiki, Wydział Nauk Społecznych, Katolicki Uniwersytet Lubelski Jana Pawła II; adres do korespondencji: Al. Racławickie 14, 20-950 Lublin; e-mail: adammaj@kul.lublin.pl; ORCID: https://orcid.org/0000-0002-0240-8013. 
analizy determinuje cel teoretyczno-praktyczny opracowania, jakim jest ukazanie potencjału pedagogiki personalistycznej w procesie wychowania i wsparcia psychopedagogicznego dzieci i młodzieży doświadczających lęku.

\section{RÓŻNE OBLICZA LĘKU}

Fenomen lęku jest złożony w odniesieniu do jego istoty, rodzajów, przyczyn, przejawów, skutków, dynamizmu, trwałości, funkcji, sposobów reakcji podmiotowej i pomocy zewnętrznej. Liczne badania nad ludzkim lękiem doczekały się wielu publikacji, ukazując pogłębioną wiedzę i jej rozwój, czego obrazem jest wciąż doskonalona klasyfikacja zaburzeń lękowych w ujęciu psychologicznym (ASD) czy psychiatrycznym (ICD).

Prezentując zaledwie wybrane zagadnienia opisujące lęk, trzeba podkreślić, że jest on stanem emocjonalnym, niejasnym, nieprzyjemnym, charakteryzującym się ,przeżywaniem obaw, strachu, stresu i przykrości” (Reber, 2000, s. 28), czyli „przykrym, intensywnie odczuwalnym stanem złego samopoczucia, wywołanym niejasnym wrażeniem niesprecyzowanego i bliskiego zagrożenia, wobec którego człowiek czuje się bezradny i bezsilny" (Sillamy, 1994, s.138). Lęk jest stanem podobnym do strachu, z tym że strach pozostaje reakcją wobec realnego zagrożenia.

Doświadczeniom emocjonalnym lęku towarzyszą zwykle objawy behawioralno-fizjologiczne, które występują $\mathrm{w}$ różnych konfiguracjach $\mathrm{i}$ intensywności. Stan emocjonalny może charakteryzować się zaburzonymi reakcjami świadomościowymi i poznawczymi, np. postrzegania, uwagi, myślenia logicznego, a także behawioralno-fizjologiczny, np. drżeniem mięśni, wzrostem ciśnienia krwi, przyśpieszoną akcją serca, poceniem się, zaburzeniem oddychania, biegunką, zahamowaniem ruchowym, tikami, płaczem, krzykiem, agresją (zob. Harwas-Napierała, 1987, s. 27). Na strukturę zjawiska lęku składa się: stan emocjonalny - negatywny, poczucie niepewności; zagrożenie - poczucie niebezpieczeństwa, wyobrażone wewnętrznie, subiektywnie, czasem pod wpływem bodźców zewnętrznych; zaburzenie somatyczne - fizjologiczne, behawioralne, poznawcze (zob. Janowski, 2004, s. 924). Natomiast przyczyny lęku są w pełni rozpoznane.

Wyróżnia się stan lęku i lęk jako cechę osobowości. Stan lęku wiąże się z konkretną sytuacją wywołującą lęk, a lęk jako cecha, niezależnie od sytuacji, odnosi się do dyspozycji osobowościowej reagowania lękiem wobec subiektywnie odczuwanego niebezpieczeństwa, bowiem „może być elementem 
trwałych indywidualnych predyspozycji do emocjonalnego reagowania na wszelkie, nawet mało awersyjne, bodźce otoczenia i postrzegania ich jako sygnały zagrożenia" (Werka, Zagrodzka, 2009, s. 20).

Występują różne klasyfikacje rodzajów lęku - ze względu na treść A. Kępiński wyróżnia lęk biologiczny, społeczny, moralny, dezintegracyjny (Kępiński, 2002, s. 98). Lęk biologiczny - spowodowany jest odczuciem zagrożenia podstawowej wartości biologicznej, jaką jest życie własne czy całego gatunku. Lęk społeczny - dotyczy relacji jednostki ze środowiskiem społecznym, szczególnie niebezpieczeństwa odrzucenia, wykluczenia. Lęk moralny - wiąże się z funkcjonowaniem sumienia, zaś dezintegracyjny - jest wyrazem rozpadu dotychczasowego porządku świata (Kępiński, 2002, s. 130).

W zakresie funkcjonalnym wyróżnia się lęk odczuwany - dotyczy aktualnie przeżywanej przykrej sytuacji; domniemany - stan emocjonalny związany z wyobrażeniem zagrożenia; ukryty - ujawniony w innej postaci; wolnopłynący - głęboki nieokreślony niepokój; paniczny - ostry, budzący przerażenie napad lęku związany z objawami somatycznymi; agitacja - intensywny lęk powiązany z niepokojem ruchowym; fobiczny - lęk wobec konkretnej sytuacji, budzącej zagrożenie i powodującej jej unikanie; antycypacyjny - oczekiwanie przed mogącą wystąpić trudną sytuacją.

Lęk jest przeżywany w sposób zróżnicowany, zindywidualizowany, z różnorodną intensywnością, nasilaniem. Można mówić o zróżnicowanym poziomie lęku na kontinuum między niskim a wysokim poziomem. Nasilenie niskie lęku może pełnić pozytywną, motywacyjno-adaptacyjną funkcję - sygnalizuje zagrożenie, mobilizuje do obrony, pobudza do działania, natomiast nasilenie wysokie pełni negatywną, dezadaptacyjną funkcję - jest szkodliwe dla psychiki człowieka i jego funkcjonowania (Harwas-Napierała, 1987, s. 30-31).

$\mathrm{O}$ ile lęk jest normalną odpowiedzią na zagrożenia, pełniąc funkcję ostrzegawczą, motywacyjną i inspirującą do określonego zachowania, o tyle przewlekłość, uporczywość, wysokie nasilenie wskazują na zaburzenie lęku, powodujące destrukcyjne skutki dla osobowości i funkcjonowania człowieka.

Zaburzenia lękowe są grupą zaburzeń psychicznych, które w klasyfikacji DSM-5, opublikowanej w 2013 r. przez Amerykańskie Towarzystwo Psychiatryczne (zob. Amerykańskie Towarzystwo Psychiatryczne, 2020) obejmują takie zaburzenia, jak: separacyjne zaburzenie lękowe - lęk przed rozstaniem z najbliższymi; mutyzm selektywny - zahamowanie mówienia w pewnych okolicznościach; fobia swoista - silny, nieuzasadniony lęk w kontakcie z konkretnym obiektem lub sytuacją; społeczne zaburzenie lękowe (fobia społeczna) - lęk wobec niektórych lub wszystkich sytuacji 
społecznych; zaburzenie lękowe uogólnione - przesadna reakcja lękowa na obciążające zdarzenia życiowe; agorafobia - lęk przed przebywaniem na otwartej przestrzeni, w miejscach publicznych, pośród tłumu; zespół lęku uogólnionego - ogólny, przewlekły i niczym nieuzasadniony lęk przed nieszczęściem (zob. Möller, 2018, s. 612).

W pedagogice lęk definiowany jest jako niepokój, „rodzaj emocji zbliżonej do strachu, której nie można łatwo rozpoznać lub usunąć” (Okoń, 2004, s. 274). Jest on grupą reakcji emocjonalnych, wyzwolonych przez bodźce płynące z zewnątrz lub wewnątrz organizmu, które posiadają swoiste właściwości. Szczególnym przedmiotem analizy pedagogicznej jest tzw. lęk szkolny, który przede wszystkim dotyczy uczniów i ich doświadczenia psychofizycznego, związanego z odczuwaniem rzeczywistości szkolnej jako zagrożenia osobistego. Czasem występuje jako reakcja na wymagania szkolne, funkcjonowanie środowiska szkolonego, lub też jako mechanizm przerzucenia postaw lękowych ze środowiska rodzinnego na szkolne (Obuchowska, 1993, s. 346).

Lęk i zaburzenia lękowe, występujące w jakiejkolwiek postaci, są zjawiskiem obciążającym funkcjonowanie wychowanka, jego rozwój i wychowanie. $\mathrm{Z}$ jednej strony wymaga ono rozpoznania $\mathrm{w}$ trafnej diagnozie, $\mathrm{z}$ drugiej wsparcia psychologicznego, niekiedy psychiatrycznego, zawsze pedagogicznego.

\section{OD TEORII OSOBY DO TEORII WYCHOWANIA PERSONALISTYCZNEGO}

W kontekście ogólnej prezentacji zjawiska lęku, trzeba postawić pytania pedagogiczne: jak w procesie wychowania uwzględniać zachowania wynikające z doświadczenia lęku przez wychowanka, jakie są możliwości wsparcia jego rozwoju i wychowania?

$\mathrm{Na}$ te pytania odpowiada pedagogika jako nauka, która nie tylko opisuje i wyjaśnia zjawiska wychowawcze, lecz także określa ich podstawy filozoficzne i aksjologiczne oraz formułuje aplikacje prakseologiczne dla procesu wychowania.

W tej perspektywy przedmiotem poniższej analizy jest jeden ze współczesnych kierunków pedagogicznych - pedagogika personalistyczna, zwłaszcza jej podstawy, które w dalszej części będą stanowić szczegółowe odniesienie do zjawiska lęku.

Pedagogika personalistyczna $\mathrm{w}$ wymiarze teoretycznym nawiązuje do koncepcji filozoficznej personalizmu, w którego centrum jest postrzeganie 
człowieka jako osoby. I. Dec wskazuje na różnorodne nurty personalizmu, wśród nich główne - humanizmu materialistycznego oraz teistycznego. Personalizm teistyczny stanowi podstawę dla pedagogiki personalistycznej w jej chrześcijańskim ujęciu, które jest tu rozpatrywane (Dec, 2008, s. 303-312).

Specyfikę pedagogiki personalistycznej zasadniczo charakteryzuje teoria osoby, której podstawę stanowi chrześcijańska wizja człowieka - antropologia biblijna, filozoficzna i teologiczna.

Biblijna prawda o człowieku nie jest wykładnią teoretyczno-systematyczną, lecz religijno-egzystencjalną, ukazuje człowieka jako Imago Deistworzonego na obraz i podobieństwo Boże ( $R d z 1,26-27)$, partnera zbawczego dialogu z Bogiem, wezwanego do rozwoju swojego człowieczeństwa w doczesności i zbawienia w wieczności, łącząc w sobie wymiar naturalny, nadprzyrodzony i eschatologiczny - przekraczający doczesność i śmierć (Bagrowicz, 2000, s. 125).

Chrześcijańska antropologia filozoficzna, nawiązując do myśli Arystotelesowskiej, do Boecjusza i św. Tomasza z Akwinu, formułuje nie tylko zasadniczą tezę, że człowiek jest osobą (persona est naturae rationalis individua substantia), lecz także określa istotę osoby i jej zasadnicze atrybuty, czyli substancjalność (samodzielność ontyczną, samoistność), indywidualność (konkretność, jedyność, niepowtarzalność), rozumność (uzdolnienie do myślenia), istnienie wewnętrznego ,ja” (Kowalczyk, 2000, s. 21-28).

Teologiczna koncepcja człowieka oparta jest głównie na dogmacie o stworzeniu - pochodzeniu oraz naturze rzeczywistości i człowieka; o odkupieniu - zranieniu grzechem człowieka i jego odkupieniu przez Chrystusa; o uświęceniu - środkach rozwoju, zwłaszcza przez miłość i sakramenty, ku pełni człowieczeństwa i zbawienia (Mastalski, 1998, s. 75).

Chrześcijańską wizję człowieka jako osoby rozwija teoria personalizmu i jej różnorodne nurty oraz pedagogika personalistyczna w inspiracji chrześcijańskiej.

Ujmując koncepcję osoby ludzkiej w personalizmie, można wyróżnić jej trzy wymiary: strukturalny, społeczny i transcendentalny, które syntetycznie opisują jej integralną specyfikę.

Wymiar strukturalny ukazuje osobę jako istotę stworzoną na obraz i podobieństwo Boże, osobę - substancjalną jedność fizyczną, psychiczną i duchową (element duchowy istotnie różni się od sfery psychicznej) (zob. Krąpiec, 1998, s. 31-56), konkretną i niepowtarzalną, posiadającą własną godność, rozumność, wolność, zdolność do miłości i rozwoju - do aktualizacji swojego potencjału ludzkiego. Osoba spełnia się w czynie, w którym trzy akty: 
poznania (rozum), uczucia (miłość) i woli (wolność) „wzajemnie się warunkują w życiu osobowym" (Krąpiec, 1991, s. 381).

Wymiar społeczny charakteryzuje osobę jako istotę społeczną, która żyje w społeczeństwie i realizuje swój potencjał ludzki w spotkaniu i służbie dla innych. Istnienie ontyczne osoby (tożsamość) dopełnia deontyczne, czyli istnienie „dla”, tworząc całość i jedność bytu ludzkiego (Nowak, 1999, s. 304-309). Społeczny wymiar osoby charakteryzuje prymat osoby wobec społeczeństwa, którego nie jest własnością i zdeterminowaną częścią.

Wymiar transcendentalny wskazuje na możność „wyjścia” człowieka poza własny świat istnienia, przekraczania swojego ,ja” osobowego. Dzięki temu osoba, przekraczając naturę, tworzy kulturę i kształtuje społeczeństwo. Bytowa otwartość osoby ludzkiej uzdalnia do transcendencji ku Bogu, w którym człowiek odnajduje absolutne TY i możliwość pełni życia ludzkiego.

Ogólnie zarysowana koncepcja człowieka w personalizmie i pedagogice personalistycznej skłania do kilku najistotniejszych wniosków. Podstawowy dotyczy tezy o wyjątkowej wartości człowieka z tej racji, że jest osobą. Kolejny wiąże się z całościowym ujęciem osoby ludzkiej, wszystkich jej wymiarów - od fizycznego po duchowy, religijny: jest to koncepcja integralna. Trzeba też podkreślić, że osoba ludzka jest zdolna do rozwoju, z jednej strony ,jest” (wymiar ontyczny, statyczny), z drugiej „staje się” (wymiar dynamiczny, relacyjny). Miarą rozwoju osobowego jest rozwój integralny ku pełni człowieczeństwa (Nowak, 1999, s. 304-307).

Integralny rozwój człowieka jako osoby domaga się adekwatnego wsparcia wychowawczego, wychowania integralnego, bowiem teoria osoby implikuje teorię wychowania i odwrotnie: teoria wychowania (praktyka także) zawsze zakłada (intencjonalnie lub nieintencjonalnie) określoną wizję człowieka (zob. Nowak, 1999, s. 312-322).

Spójną i teoretycznie uzasadnioną koncepcję integralnego rozwoju i wychowania człowieka przedstawił S. Kunowski. W procesie rozwoju człowieka S. Kunowski wyróżnił pięć warstwic, stanowiących podłoże wychowania, przypisując każdej z nich dynamizm warunkujący wychowanie. Warstwami tymi są: biologiczna - organizm (dynamizm bios), psychologiczna - psychika (logos), socjologiczna - osoba społeczna (etos), kulturologiczna twórca kultury (agos), światopoglądowa (religijna) - istota duchowa, religijna, zdolna zmierzyć się z losem (Kunowski, 1996, s. 172-181, 197). Każda warstwa ma swój czas rozwoju i osiągnięcia dojrzałości, bowiem „rozwój coraz wyższych struktur integruje, włącza w całość działania struktur wcześniejszych, na skutek czego postępowanie człowieka w sposób naturalny 
doskonali się i szlachetnieje, staje się coraz bardziej ludzkie" (Kunowski, 1996, s. 216). Na każdym etapie rozwoju konieczne jest oddziaływanie wychowawcze i aktywność wychowanka.

W tym kontekście wychowanie integralne jest wspieraniem integralnego rozwoju, czyli „wspomaganiem wychowanka w drodze do osiągnięcia pełni człowieczeństwa - w harmonijnym rozwoju swych potencjalności tkwiących w poszczególnych sferach: fizycznej, psychicznej, społecznej, kulturowej, religijnej oraz ich integrowaniu ze sobą" (Chałas, 2007, s. 11).

Inne przesłanki teoretyczne procesu wychowania w ujęciu personalistycznym, zdaniem M. Nowaka, to:

- priorytetowe w wychowaniu uzdolnienie wychowanka do kierowania własnym rozwojem;

- wychowanie traktowane jako „wzbudzenie osoby w wychowanku”;

- wychowanek ujmowany jako zasadniczy czynnik wychowania, a wychowawca jako osoba wspomagająca;

- wychowanek nie stanowi własności rodziny czy państwa;

- respektuje się rolę szkoły oraz powiązania procesu dydaktycznego z wychowaniem (odrzucenie koncepcji szkoły „neutralnej” i realizacja integralnego humanizmu);

- eksponuje się pierwszeństwo wychowawcze rodziny; respektuje się godność i podmiotowość wychowanka (Nowak, 1999, s. 258-259).

Pedagogika personalistyczna podkreśla dialogiczny wymiar procesu wychowania, definiując wychowanie jako ,całokształt sposobów i procesów pomagających istocie ludzkiej, zwłaszcza przez interakcję, urzeczywistniać i rozwijać swoje człowieczeństwo" (Tarnowski 1993, s. 66). Rozwój człowieczeństwa ku jego pełni osiąga się w urzeczywistnianiu wartości według określonego porządku, hierarchii, odpowiadającej personalistycznemu kryterium, np. według koncepcji integralnego rozwoju i wychowania S. Kunowskiego - od najniższych do najwyższych - wartości zmysłowo-witalne, intelektualno-emocjonalne, moralno-społeczne, kulturowe, duchowo-religijne.

Pedagogika personalistyczna kształtowana wokół kategorii osoby ludzkiej, ujmowanej całościowo i realistycznie, tworząc teorię wychowania integralnego, chroni ,przed różnego rodzaju modnymi dziś, a zarazem zgubnymi, redukcjonizmami, mającymi swoje korzenie w błędnym rozumieniu osoby ludzkiej" (Rynio, 2004, s. 17).

Na każdym etapie rozwoju konieczne jest oddziaływanie wychowawcze i aktywność wychowanka. Podstawę procesu wychowania stanowią wartości 
w ich hierarchicznym układzie, opartym na osobowym kryterium - od najniższych po najwyższe, duchowo-religijne.

\section{LĘK W PERSPEKTYWIE PERSONALISTYCZNYCH KATEGORII}

Zarysowane elementy personalizmu i pedagogiki personalistycznej umożliwiają podjęcie $\mathrm{w}$ ich świetle analizy zjawiska lęku doświadczanego przez wychowanka w procesie jego wychowania.

Rozpatrując podstawową kategorię personalistyczną, jaką jest osoba, trzeba podkreślić, że wychowanie jest rzeczywistością międzyludzką, dokonuje się w spotkaniu osoby wychowawcy z osobą wychowanka, wymaga zaangażowania ze strony wychowawcy i wychowanka. Doświadczenie lęku przez wychowanka może utrudniać komunikację wychowawczą i efektywność procesu wychowania. Dlatego istotne jest holistyczne, integralne i realistyczne rozpoznanie sytuacji wychowanka oraz odpowiednie nastawienie wobec jego osoby. Dla wychowawcy w rodzinie (ojciec, matka) czy w szkole (nauczyciel) nie może być obojętne doświadczenie wychowanka (dziecka, ucznia), jego przeżycia lękowe, ich intensywność czy uporczywość. W przypadku zaburzeń lęku konieczna jest ingerencja specjalistyczna i zastosowanie farmakoterapii czy psychoterapii. Ale nawet wtedy, a może zwłaszcza wtedy, konieczne jest oddziaływanie wychowawcze i adekwatna terapia pedagogiczna. Lęk, ograniczając lub dezintegrując chwilowo, na dłuższy czas lub niemal na stałe funkcjonowanie wychowanka w sferze psychicznej i fizycznej, rzutuje na jego relacje społeczne, wybory moralne, aktywność edukacyjną czy duchową. Koncentracja tylko na zjawisku lęku jako takim nie służyłaby skutecznie procesowi rozwoju i wychowania wychowanka. Tak w terapii, jak i w wychowaniu nie chodzi tylko o jednostkę chorobową, o czynnik zagrożenia, który wymaga bezpośredniej pomocy, ale o wychowanka jako osobę w całej jej złożoności i pełni.

Wychowanek traktowany osobowo i podmiotowo nie spotka się z bagatelizowaniem jego lęku. Z względu na jego godność osobową wychowawca zobligowany jest do rozpoznania tego zjawiska u wychowanka i uwzględnienia go w procesie wychowania. Jest to realizm wychowawczy, akcentowany $\mathrm{w}$ personalizmie, zobowiązujący do zaangażowania w los wychowanka, w jego egzystencjalne doświadczenie. Wychowanek bowiem jest podmiotem osobowym z jego własną biografią, skłonnościami, pragnieniami, potrzebami, samooceną i wartościowaniem wydarzeń dokonujących się wokół niego. 
Realizm jest twórczym podejściem do wychowanka, w którym istotne są: zainteresowanie jego osobą oraz akceptacja i bezinteresowność wychowawcy. Ze strony wychowawcy realizm przejawia się w diagnozie sytuacji wychowanka (Bryńska, 2005; Popek, 2004).

O ile diagnoza w środowisku wychowawczym rodziny powinna być prowadzona wrażliwie, z zachowaniem zdrowego rozsądku, głównie przez obserwację, o tyle od diagnostyki w środowisku szkolnym wymaga się profesjonalizmu - posiadania elementarnej wiedzy psychologicznej, pedagogicznej i umiejętności diagnostycznych, oczekiwanych od nauczycieli i pedagogów szkolnych.

Proces diagnozowania w szkole ma charakter specjalistyczny, wymaga zachowania odpowiednich procedur i posiadania przez diagnostę (nauczyciela, pedagoga szkolnego) stosownych kompetencji. Strukturę diagnozy tworzy opis zjawiska, ocena - interpretacja rozpoznanego zjawiska, prognoza - negatywna i pozytywna, plan pomocy psychopedagogicznej (Jarosz, Wysocka, 2006, s. 19-20). Podstawową metodą diagnostyczną jest obserwacja, ale w trakcie indywidualnego procesu diagnozowania można posłużyć się wieloma innymi metodami i technikami, odpowiednimi do problematyki diagnozy i wieku osoby diagnozowanej, takimi jak: ankieta, wywiad, techniki socjometrii, techniki projekcyjne. Prowadzenie diagnozy wymaga kompetencji diagnosty. B. Skałbania określa je jako interpretacyjne (zakładające wiedzę w danej dziedzinie), komunikacyjne i metodologiczne (Skałbania, 2013, s. 58). Wydaje się, że z punktu widzenia personalizmu pedagogicznego należałoby dodać kompetencje osobowościowe, związane z cechami i postawami diagnosty (empatia, kultura osobista, serdeczność itp.).

Diagnostyka szkolna obejmuje osobę ucznia, m.in. jego właściwości psychiczne, potrzeby, zdolności, funkcjonowanie społeczne, osiągnięcia edukacyjne, sytuację rodzinną, a także procesy wychowawcze, dydaktyczne, opiekuńcze i profilaktyczne zachodzące w klasie szkolnej i szkole (Janowski, 2002, s. 36-66).

W obszarze diagnostyki szkolnej mieści się zjawisko lęku uczniowskiego. Dzięki obserwacji wychowanka, sposobu jego zachowania, reakcji na różnorodne bodźce, relacje społeczne i wyrażane poglądy, można wprost lub pośrednio zdiagnozować jego stan, jego doświadczenia emocjonalne. Obserwowalne są fizjologiczne przejawy lęku: zaczerwienienie na twarzy, szyi, drżenie rąk, płacz czy łzy w oczach, niepokój wyrażony w spojrzeniu, czasem niespodziewana konieczność skorzystania $\mathrm{z}$ toalety, w wyrazie behawioralnym osłabienie organiczne, zakłócenia w sferze sensomotorycznej. Także 
w zachowaniach społecznych można odczuć lęk wychowanka wyłączającego się z grupy, niepewnego czy nadmiernie emocjonalnego, nawet agresywnego. Diagnozie służą także wytwory kulturowe wychowanka, szczególnie w wieku dziecięcym, stanowiące zwykły sposób ujawniania jego emocji. Diagnoza powinna dotyczyć także analizy niepowodzeń dydaktycznych ucznia, bowiem lęk nie sprzyja aktywności intelektualnej, również nadmierna motywacja, lękliwie skierowana na sukces, bywa powodem nieumiejętności znoszenia nawet małych porażek. Niezwykle ważny jest kontakt osobisty wychowawcy z wychowankiem, dyskretny, budzący zaufanie, w którym swobodnie ujawnia się doświadczenie wychowanka i artykułuje się jego zjawisko lęku.

Wszechstronna ocena zachowań i postaw wychowanka implikuje realistyczną diagnozę. W jej realizacji mogą pomóc rodzice, pedagog szkolny, nauczyciele oraz inni specjaliści, terapeuci, lekarze, jeśli problem jest szczególnie trudny w zakresie natężenia, częstotliwości, objawów i skutków. Trzeba jednak pamiętać o współdziałaniu z wychowankiem na wszystkich etapach diagnozy, respektując jego godność osobową.

Zdiagnozowana sytuacja wychowanka wymaga od pedagoga (rodzica, nauczyciela, wychowawcy, pedagoga szkolnego) odpowiednich działań, przede wszystkim wychowawczych, czasem terapeutycznych, a w wyjątkowych sytuacjach także specjalistycznych. Pedagog, mając do czynienia z osobą wychowanka taką, jaką jest, musi sobie odpowiedzieć na pytanie, co w tej sytuacji uczynić, żeby skutecznie pomóc wychowankowi, nie tylko pokonać określoną trudność, lecz nade wszystko wspierać jego rozwój, wyzwalając potencjał tkwiący w jego osobie.

$\mathrm{W}$ tej perspektywie na uwagę zasługują kolejne kategorie personalizmu pedagogicznego. Do nich należy godność, miłość, rozumność, wolność.

Godność jest taką wartością, z którą należy się liczyć nie tylko w diagnozowaniu i wychowaniu, lecz także w różnych formach terapii, bowiem może inspirować proces pokonywania lęku. Godność można rozpatrywać jako daną i zadaną (osobowa, „niezbywalna”) i nabywaną (osobowościowa, „utracalna"). Pierwsze ujęcie wynika z samej istoty bycia człowiekiem i jest wartością wrodzoną, przysługującą każdemu człowiekowi niezależnie od jego wieku, rasy, płci, kondycji zdrowotnej i moralnej, subiektywnego upodobania, statusu społecznego czy innych czynników. Źródłem drugiego jest doskonałość, jaka rodzi się w działaniu moralnie wartościowym i utrwala się w osobowości, dzięki wychowaniu, samowychowaniu i wpływom środowiska (Szostek, 1998, s. 45-46). 
Wychowanek doświadczający lęku powinien odkrywać wartość własnej osoby i jej niezbywalną godność, a zarazem budować godność moralną, nabywaną stylem życia. W procesie wychowania i terapii pedagogicznej wychowanek doświadczający lęku nie tylko ma się spotkać z reakcją na swoje problemy, ale przede wszystkim przeżywać akceptację dla swojej osoby: dobrze, że jesteś; stanowisz wielką wartość; ciesz się swoim istnieniem; bądź pewny, że jesteś szanowany, a nawet kochany. Szczera i bezinteresowna akceptacja osoby wychowanka jest dla niego zasadniczym wsparciem. Personalizm chrześcijański podkreśla, że właściwym podejściem do bliźniego jest akceptacja posunięta do miłości. Wzywa do niej Jan Paweł II, formułując tzw. normę personalistyczną, polegającą na afirmacji ponadrzeczowej, ponadkonsupcyjnej i ponadużytkowej wartości osoby ludzkiej, która nigdy nie może być środkiem, a zawsze celem (Nowak, 1999, s. 319-320). Jan Paweł II w UNESCO stwierdził, że „trzeba do końca i integralnie widzieć człowieka jako szczególną, samoistną wartość, jako podmiot związany z osobową transcendencją. Trzeba tego człowieka afirmować dla niego samego, nie dla jakiejkolwiek racji i względów - jedynie dla niego samego. Trzeba tego człowieka po prostu miłować dlatego, że jest człowiekiem - trzeba wymagać od niego miłości ze względu na szczególną godność, jaką posiada" (Jan Paweł II, 1988, s. 57-58). Miłość jest właściwym motywem wychowania i terapii. Doświadczając miłość wychowanek może uczyć się akceptacji swojej osoby, pomimo trudnych i przykrych przeżyć, w tym lęku, skłonności do reakcji lękliwych i niepewności. Akceptacja siebie, słuszna miłość siebie stanowi siłę motywacji do terapii i wychowania, bez względu na bieżące porażki czy sukcesy w przezwyciężaniu lęku. Miłość jest jak światło odkrywające ukryte możliwości życia i rozwoju. Miłość przeżywana religijnie umożliwia budowanie głębszej akceptacji i trwałej więzi z Bogiem.

Personalistyczne postrzeganie miłości nie utożsamia jej z emocjami, ale angażuje też rozumność i wolność. W perspektywie miłości może dokonać się racjonalna i realistyczna samoocena wychowanka i jego stanów lękowych. Racjonalność zaś tworzy w świadomości wychowanka dystans do pojawiających się lęków, umożliwia znoszenie swoich stanów i poszukiwanie sposobów radzenia sobie $\mathrm{w}$ trudnościach. Z pewnością wymaga czasu i działań pomocowych.

Podobnie jest z wolnością. Stanowi ona naturalny atrybut człowieka. Wychowanek, uświadamiając sobie wewnętrzną wolność „od” i pragnienie przezwyciężenia lęku, jednocześnie może pokierować swoją wolnością „do”: do wyboru swojego zachowania pomimo bieżących trudności, do wyboru stylu 
życia i drogi życiowej. W doświadczeniu wolności trzeba upatrywać mocy zaangażowania się wychowanka w swój los, niezamykania się w sobie, w nadaniu życiu głębszego sensu.

Wolność powiązana jest ze światem wartości. Wychowanek, jak każdy człowiek, wciąż wartościuje, wybiera wartości, ceniąc jedne jako bardziej znaczące od innych, w ten sposób wyrażając i zarazem kształtując własną ich hierarchię. Wychowanie ku wartościom staje się szczególnym zadaniem wobec wychowanka przeżywającego lęk. Trzeba mu pokazać horyzonty rzeczy ważnych, do których warto i trzeba dążyć, respektując personalistyczną hierarchię wartości. W tak uporządkowanym świecie wartości wychowanek może odkrywać nie tylko siebie, lecz także innych i wielkie sprawy jako zadania do realizacji. Od jego wolności ostatecznie zależy wybór wartości, jak i zaangażowanie się w swoje życie, a nie tylko w pokonanie lęku. Wolność wiąże się z odpowiedzialnością za swoje wybory i życie takie, jakie jest i jakie może być (Chałas, 2006, s. 138-200).

Powyższe kategorie personalistyczne sugerują stałą aktywność wychowawcy i wychowanka. Pokonanie lęku wychowanka wymaga zaangażowania wychowawcy w proces wychowawczy, a czasem w zastosowaną terapię pedagogiczną. Zawsze zakłada współudział wychowanka, jego wolne i świadome kształtowanie siebie jako osoby. Dopiero na tym fundamencie można budować różne modele terapeutyczne dla przeżywających zaburzenia lękowe.

Prezentowane analizy z perspektywy pedagogiki personalistycznej w jej chrześcijańskim ujęciu sugerują integralne podejście do wychowanka jako osoby przeżywającej lęk. Inspirują do adekwatnej aktywności wychowawczej i terapii pedagogicznej, respektującej godność, rozumność, wolność i zdolność do miłości.

\section{BIBLIOGRAFIA}

AMERYKAŃSKIE TOWARZYSTWO PSYCHIATRYCZNE (2020). Kryteria diagnostyczne zaburzeń psychicznych DSM-5. Wrocław: Edra Urban \& Partner.

BAgrowicz, J. (2000). Edukacja religijna współczesnej młodzieży. Źródła i cele. Toruń: Wydawnictwo UMK.

BRYŃSKA, A. (2005). Zaburzenia lękowe i zaburzenie obsesyjno-kompulsyjne. W: T. WolAŃCZYK, J. KOMENDER (red.), Zaburzenia emocjonalne i behawioralne u dzieci (s. 147-178). Warszawa: PZWL. 
CHAŁAS, K. (2007). Wychowanie ku wartościom wiejskim jako szansa integralnego rozwoju wychowanka. Lublin: Wydawnictwo KUL.

ChaŁAs, K., (2006). Wychowanie ku wartościom. Elementy teorii i praktyki, t. 1. Lublin-Kielce: Jedność.

Dec, I. (2008). Personalizm w filozofii (próba systematyzacji). W: M. RuseCKI (red.), Personalizm polski. Lublin: Wydawnictwo KUL.

FrankL, V.E. (1984). Homo Patiens. Warszawa: PAX.

HARWAS-NAPIERAŁA, B. (1987). Czynniki społeczno-rodzinne w ksztaltowaniu się lęku u młodzieży. Poznań: Wydawnictwo Naukowe UAM.

HoŁub, G. (2010). Pacjent jako osoba. W: W. Chańska, J. HARTMAn (red.), Bioetyka w zawodzie lekarza (s. 39-48). Warszawa: Wolters Kluwer Polska.

JAN PAweŁ II (1988). W imię przyszłości kultury. Przemówienie w UNESCO (2.06.1980). W: M. Radwan, S. WylężeK, T. Gorzkula (red.), Jan Pawet II. Wiara i kultura. Dokumenty, przemówienia, homilie (s. 51-68). Rzym-Lublin: RW KUL.

JANOWSKI, A. (2002). Pedagogika praktyczna: zarys problematyki, zdrowy rozsądek, wyniki badań. Warszawa: Fraszka Edukacyjna.

JANOWSKI, K. (2004). Lęk. Aspekt psychologiczny. W: Encyklopedia katolicka, t. X (s. 924-926). Lublin: Towarzystwo Naukowe KUL.

Jarosz, E., Wysocka, E. (2006). Diagnoza psychopedagogiczna. Podstawowe problemy i rozwiazania. Warszawa: Wydawnictwo Akademickie „Żak”.

KĘPIŃSKI, A. (2002). Lęk. Kraków: Wydawnictwo Literackie.

KowAlczYK, S. (2000). Wolność natura i prawem człowieka. Indywidualny i spoleczny wymiar wolności. Sandomierz: Wydawnictwo Diecezjalne i Drukarnia w Sandomierzu.

KRĄPIEC, M.A. (1991). Ja - czlowiek. Zarys antropologii filozoficznej. Lublin: Redakcja Wydawnictw KUL.

KrąPIEC, M.A. (1998). Człowiek jest osobą. W: M. WósciK (red.), Człowiek. Osoba. Płeć (s. 3156). Łomianki: Pomoc Rodzinie.

KunOwski, S. (1996). Podstawy współczesnej pedagogiki. Warszawa: Wydawnictwo Salezjańskie.

MASTALSKI, J. (1998). Elementy teorii wychowania dla katechetów. W: M. ŚNIEŻYŃSKI (red.), Pedagogika w katechezie (s. 73-93). Kraków: Wydawnictwo Naukowe Papieskiej Akademii Teologicznej.

MöLLER, H.J. (2018). Możliwości i ograniczenia DSM-5 w polepszeniu klasyfikacji i diagnozy zaburzeń psychicznych. Psychiatria Polsk, 52(4), 611-628.

NowaK, M. (1999). Podstawy pedagogiki otwartej. Lublin: Wydawnictwo KUL.

OBuchowsKa, I. (1993). Lęk, lęk szkolny. W: W. POмYкAŁo (red.), Encyklopedia pedagogiczna (s. 344-346). Warszawa: Fundacja Innowacja.

ОкоŃ, W. (2004). Nowy słownik pedagogiczny. Warszawa: Wydawnictwo Akademickie „Żak”.

POPEK, L. (2004). Zaburzenia emocjonalne rozpoczynające się w dzieciństwie. W: I. NAMYsŁowSKA (red.), Psychiatria dzieci i młodzieży (s. 129-141). Warszawa: PWZL.

RAMSEY, P. (1977). Pacjent jest osoba. Warszawa: PAX.

ReBer, A. (2000). Stownik psychologii. Warszawa: Wydawnictwo Naukowe Scholar. 
Rozporządzenie Ministra Edukacji Narodowej (2017) w sprawie zasad organizacji i udzielania pomocy psychologiczno-pedagogicznej w publicznych przedszkolach, szkołach i placówkach (Dz. U. 2017, poz. 1591 z póź. zm.).

RYNIO, A. (2004). Integralne wychowanie w myśli Jana Pawła II. Lublin: Wydawnictwo KUL.

Sillamy, N. (1994). Stownik psychologii. Katowice: „Książnica”.

SkaŁbaniA, B. (2013). Diagnostyka pedagogiczna. Wybrane obszary badawcze i rozwiazania praktyczne. Kraków: Impuls.

SzosteK, A. (1988). Wokól godności, prawdy i miłości. Lublin: Redakcja Wydawnictw KUL.

Werka, T., ZAGrodzKA, J. (2009). Strach i lęk w świetle badań neurobiologicznych. W: M. FAJKOWSKA, B. SzYMURA (red.), Lęk: geneza, mechanizmy, funkcje (s. 17-25). Warszawa: Wydawnictwo Naukowe Scholar.

\section{ZJAWISKO LĘKU W PERSONALISTYCZNEJ PERSPEKTYWIE}

\section{STRESZCZENIE}

Lęk jest doświadczeniem osobowym. Wymaga holistycznej i integralnej interwencji, której teoretyczną podstawę może stanowić pedagogika personalistyczna. W jej centrum jest kategoria osoby, jej godność, rozumność, wolność, zdolność do miłości. W ujęciu chrześcijańskim także miłosierdzie. Te kategorie określają realistyczną przestrzeń integralnej aktywności wychowawczej i terapeutycznej nauczyciela wobec wychowanka doświadczającego lęku.

Słowa kluczowe: lęk; pedagogika personalistyczna; osoba; integralne wychowanie.

\section{THE PHENOMENON OF ANXIETY IN A PERSONALIST PERSPECTIVE}

\section{SUMMARY}

Anxiety is a personal experience. It requires holistic and integral intervention, the theoretical basis of which can be personalistic pedagogy. At its center is the category of the person, his dignity, rationality, freedom, and ability to love. In Christian terms, also mercy. These categories define the realistic space of integral educational and therapeutic activity of the teacher towards the pupil experiencing anxiety.

Key words: anxiety; personalistic pedagogy; person; integral education. 